\title{
Glosa do wyroku Naczelnego Sądu Administracyjnego z dnia 2 sierpnia 2016 r., II FSK 3765/14
}

Teza: Warunkiem koniecznym skorzystania ze zwolnienia, o którym mowa w art. 17 ust. 1 pkt 4 u.p.d.o.p., jest przeznaczenie i wydatkowanie dochodu na jeden z celów statutowych wymienionych w tym przepisie. Nie ulega wątpliwości, że przeznaczenie i wydatkowanie dochodu powinna charakteryzować tożsamość celu, na który podatnik najpierw dochód przeznaczył, a następnie wydatkował. Ustawodawca nie zakreśla przy tym terminu, w jakim dochód przeznaczony na cel statutowy powinien być wydatkowany, jednak nie oznacza to, że wystarczy samo przeznaczenie dochodu, bez finalnej realizacji w postaci jego wydatkowania na ten konkretny cel statutowy.

\footnotetext{
$1 \quad$ LEX nr 2179955.
} 


\section{1.}

Glosowany wyrok dotyczy jednej z istotniejszych regulacji w podatku dochodowym od osób prawnych ${ }^{2}$, tj. regulacji dotyczącej zwolnień podatkowych. O ile zakres zwolnień w konkretnym przypadku może powodować wątpliwości w praktyce podatkowej, to potęgują się one wówczas, gdy ustawodawca podatkowy w konstrukcji tego zwolnienia wprowadza środki techniki prawodawczej zapewniające elastyczność tekstu aktu normatywnego, a zatem w rezultacie takie środki techniki prawodawczej, które powodują elastyczność przepisów prawa podatkowego ${ }^{3}$. Wprowadzenie bowiem takiego środka techniki prawodawczej powoduje w rezultacie uelastycznienie zakresu zwolnienia, co może prowadzić do zasadniczej różnicy stanowisk organu podatkowego i podatnika co do zakresu zwolnienia. Umieszczenie takiego środka techniki prawodawczej nie można postrzegać wyłącznie w kategoriach potencjalnej różnicy stanowisk w ustalaniu zakresu zwolnienia pomiędzy podatnikiem a organem podatkowym. Chodzi tu także o właściwe rozłożenie ciężaru podatkowego. Nie ulega wątpliwości, iż zwolnienia podatkowe - w analizowanym przypadku zwolnienia przedmiotowe - pozostają w ścisłej relacji z zakresem przedmiotowym opodatkowania. Stąd też ustawodawca podatkowy, podejmując decyzję o wprowadzeniu danego zwolnienia podatkowego, powinien liczyć się z konsekwencjami, jakie wywoła to dla kształtowania owego ciężaru podatkowego. Problem powstaje zwłaszcza wówczas, gdy normodawca wprowadzi środek techniki prawodawczej uelastyczniający dany przepis prawa podatkowego, co do którego trudno jest ocenić w momencie jego wprowadzenia, jaki będzie miał zakres w dalszym etapie jego stosowania. Inaczej mówiąc, na „etapie wejścia” danego przepisu. Można zatem użyć pewnego uproszczenia, że wprowadzając środek techniki prawodawczej uelastyczniający przepis zwolnienia podatkowego, należy mieć szczególnie na uwadze stosunek pomiędzy „momentem wejścia” danego unormowania a „momentem jego realizacji”. Stąd też wyda-

2 Ustawa z dnia 15 lutego 1992 r. o podatku dochodowym od osób prawnych (tekst jedn. Dz.U. z 2016 r., poz. 1888 ze zm., dalej: u.p.d.o.p.).

3 P. Borszowski, Określenia nieostre i klauzule generalne w prawie podatkowym, Warszawa 2017, s. 33 i n. 
je się, iż na ustawodawcy podatkowym ciąży obowiązek szczególnej dbałości, można by rzec ostrożności, przy wprowadzaniu w prawie podatkowym takich środków techniki prawodawczej, by z jednej strony doprowadzić do w miarę dużego poziomu przewidywalności ustaleń pojawiających się na dalszym etapie stosowania danego środka techniki prawodawczej, z drugiej zaś strony by stosunek pomiędzy momentem wejścia danego przepisu a momentem jego realizacji był możliwy do obrony.

To pewne problemy, jakie pojawiają się także przy analizie regulacji, którą poczynił Naczelny Sąd Administracyjny w Warszawie w glosowanym wyroku. Orzeczenie dotyczy bowiem wykładni przepisu art. 17 ust. 1 pkt 4 u.p.d.o.p., a zatem zwolnienia, które określa się jako zwolnienie podatników przeznaczających dochody na cele statutowe. Naczelny Sąd Administracyjny w Warszawie wskazał, iż przepis ten w powiązaniu z przepisem art. 17 ust. 1b u.p.d.o.p. prowadzi do konieczności akcentowania tożsamości celu w zakresie przeznaczenia dochodów na cele statutowe i jego wydatkowania. Wyrok ten jest, po pierwsze, dobrym przykładem na rolę, jaką ma pełnić orzecznictwo podatkowe przy precyzowaniu zakresu takich środków techniki prawodawczej, które użył normodawca w ramach zapewnienia elastyczności przepisów prawa podatkowego, po drugie zaś jest jednocześnie dobrym przykładem precyzowania zakresu określeń nieostrych, które ustawodawca wykorzystał w konstrukcji tego zwolnienia podatkowego.

Należy jednak zauważyć, iż wyrok ten pobudza do nieco głębszej analizy tych określeń nieostrych. Problem ten sprowadza się bowiem do analizy wpływu, jaki wywiera na zakres zwolnienia wprowadzenie takiego środka techniki prawodawczej, gdzie normodawca odwołuje się do działania w określonym celu, a zatem w tym przypadku dochodów przeznaczonych na cele statutowe oraz dochodów wydatkowanych na cele statutowe. Wymaga to $\mathrm{w}$ pierwszej kolejności rozważenia obszaru nieostrości dla określenia nieostrego dochody przeznaczone na cele statutowe oraz dla określenia nieostrego dochody wydatkowane na cele statutowe. 


\section{2.}

W pierwszej kolejności należy zauważyć, iż wskazane sformułowanie dochody przeznaczone na cele statutowe, które zarówno pojawia się w głosowanym orzeczeniu, jak i jest przyjmowane w literaturze ${ }^{4}$, zdaje się być pewnym uproszczeniem. Ustawodawca w przepisie art. 17 ust. 1 pkt 4 u.p.d.o.p. wskazuje bowiem na dochody podatników, których celem statutowym jest dana działalność, i jeżeli na te cele podatnik przeznacza dochody, mogą one podlegać zwolnieniu pod warunkiem spełnienia wymogu $\mathrm{z}$ art. 17 ust. 1b u.p.d.o.p. Przyjęte sformułowanie jest zatem założonym uproszczeniem, które pomaga „złagodzić” wyrażenie przyjęte przez normodawcę, który cel utożsamia z określoną działalnością. Należy jednakże zauważyć, że takim zwrotem posługuje się normodawca w stanowiącym uzupełnienie do badanej regulacji przepisie art. 17 ust. 1b u.p.d.o.p.

Warto przy tym podkreślić, iż normodawca niejako podwójnie kwalifikuje cel jako działalność. W pierwszej kolejności wskazuje bowiem na dochody podatników, których celem statutowym jest działalność - pierwsza identyfikacja celu z działalnością, a w drugiej kolejności wskazuje, że zwolnienie może dotyczyć części dochodów przeznaczonych na te cele, a zatem na cele określone w tym przepisie, wśród których ustawodawca umieścił także będący przedmiotem glosowanego wyroku cel w postaci działalności w zakresie ochrony zdrowia. Nie można przyjąć, iż motywem uzasadniającym identyfikację celu z działalnością było posłużenie się przez normodawcę różnym nazwaniem działalności, z jednej strony poprzez wskazanie na dany rodzaj działalności, czyli np. naukowa, a z drugiej strony poprzez wskazanie na zakres danej działalności, a zatem przykładowo w zakresie ochrony zdrowia. Pomiędzy pojęciem celu a pojęciem działalności zachodzi bowiem różnica. Celem jest bowiem pewien postulowany stan rzeczy, do którego dąży dany podmiot ${ }^{5}$, natomiast działalność oznacza pewną mierzalną aktywność podmiotu. Zasadniczo działalność

4 Jak choćby P. Małecki, M. Mazurkiewicz, CIT. Podatki i rachunkowość. Komentarz, wyd. VII, Lex, Komentarz do art. 17.

5 W prawie przyjęto także takie rozumienie celu, I. Bogucka, Funkcje prawa. Analiza pojęcia, Kraków 2000, s. 60. 
jest realizowana w określonym celu. Niewątpliwie zatem cel jest ścisłe powiązany z działalnością, przy czym pojęcia te należy odróżniać, gdyż z ich zastosowaniem mogą się wiązać różne zakresy. A zatem powstaje pytanie, w jaki sposób ustalać obszar nieostrości dla tego określenia nieostrego, by z jednej strony dać możliwość podatnikom korzystania z tego zwolnienia, a z drugiej strony, by organy podatkowe nie ograniczały jego zakresu. Wydaje się, że rozwiązanie, jakie zastosował ustawodawca, daje się uzasadnić względami zarówno praktyki, jak i pewnej ostrożności interpretacyjnej. Należy bowiem zauważyć, iż w praktyce podmioty mogą nie przestrzegać delimitacji pojęciowej pomiędzy celem a działalnością, stąd też ustawodawca nakłada niejako unormowania na takie sytuacje, gdy podatnicy identyfikują cel z tą działalnością. Ponadto znacznie łatwiej jest ustalić zakres zwolnienia w przypadku badania dochodów przeznaczonych na daną działalność bądź w zakresie tej działalności, niż w przypadku, gdy badaniu podlegałyby działania podjęte jedynie w pewnym celu. Jednak w praktyce może powstać problem w kwalifikacji tych dochodów w ramach zwolnienia, które nie są identyfikowane poprzez konkretną działalność, a jedynie poprzez określony cel w zakresie chociażby ochrony zdrowia, czego potwierdzeniem jest glosowany wyrok. Warto zatem zauważyć, że NSA w Warszawie w glosowanym wyroku nie miał wątpliwości co do identyfikowania w kategorii zwolnienia tych dochodów, które przeznaczyłby podmiot jako poprzednik prawny na działalność w zakresie ochrony zdrowia. Niewątpliwie chodziło tu o konkretny rodzaj działalności w tym zakresie realizowanej przez Zakład Opieki Zdrowotnej (ZOZ).

Ścisłe ustalenie obszaru nieostrości wychodziłoby poza ustalenia przyjęte formułą glosy. Należałoby zatem jedynie zasugerować kwestie, które można by analizować w ramach odrębnego opracowania. Sformułowanie ustawowe w przepisie art. 17 ust. 1 pkt 4 u.p.d.o.p. prowadzić może do pewnego obszaru nieostrości, który trudno jest wyeliminować poprzez wyrażenie, które przyjął ustawodawca, identyfikując cel z działalnością. Niezależnie bowiem od rozbieżności pojęciowej można ustalić obszar nieostrości, gdy idzie o dochody przeznaczone na konkretną działalność bądź w zakresie tej działalności, jak choćby w zakresie ochrony zdrowia. Obszar tej nieostrości może być znaczny, jeśli chodzi o taką 
sytuację, gdy podatnik przeznaczył dochody na określone cele, ale nie ma możliwości bezpośredniej identyfikacji dochodów z konkretnym rodzajem działalności. Powstaje w takim przypadku problem w kwalifikowaniu zwolnienia, mimo że cele statutowe zostały spełnione.

Ponadto NSA w Warszawie w glosowanym wyroku akcentował przy tym wymóg bezpośredniego realizowania celu, podzielając przy tym pogląd przyjęty przez NSA w Warszawie w wyroku z dnia 20 listopada 2000 r. ${ }^{6}$, gdzie sąd wymóg ten wywodził $\mathrm{z}$ art. 17 ust. 1b u.p.d.o.p. Nie ulega wątpliwości, iż tak określony wymóg można formułować w aspekcie dochodów przeznczonych na cele statutowe. Taki związek pomiędzy przeznaczeniem dochodów a danym celem, czyli de facto działalnością zdrowotną, wynika z tego sformułowania końcowej części przepisu art. 17 ust. 1 pkt 4 ustawy, gdzie wskazuje się na dochody w części przeznaczonej na te cele.

\section{3.}

Wskazany w poprzednim punkcie rozważań zwrot wskazujący na dochody przeznaczone na cele statutowe, niesformułowany wprost w przepisie art. 17 ust. 1 pkt 4 u.p.d.o.p., ustawodawca uzupełnia w przepisie art. 17 ust. 1b u.p.d.o.p., wskazując na zwolnienie podatników przeznaczających dochody na cele statutowe. Wydaje się, że prawodawca tym samym stara się poprawić identyfikację celu z działalnością, akcentując, iż w gruncie rzeczy chodzi mu jednak o cel, który w rozumieniu art. 17 ust. 1 pkt 4 jest działalnością. Nie rozważając szczegółowo wątpliwości, które w tym względzie pojawiają się w związku z pewnym uproszczeniem, jakie zastosował normodawca, należy ustalić obszar nieostrości, jaki ustawodawca wykreował, wprowadzając jednocześnie zasadnie wymóg wydatkowania dochodów na te cele. Obszar ten jest tym bardziej istotny, że w rezultacie stał się przedmiotem analizy NSA w glosowanym wyroku, gdzie sąd ten wskazał na konieczność dostrzegania tożsamości celu, na który podatnik dochód w pierwszej kolejności przeznaczył, a w dalszej kolejności wydatkował. Owa tożsamość stała się tym bardziej istotna, iż w sprawie będącej

$6 \quad$ FPS 9/00, ONSA z 2001 r. Nr 2, poz. 54. 
przedmiotem rozstrzygnięcia przez NSA w Warszawie dochody były przeznaczone na działalność w zakresie ochrony zdrowia przez jeden podmiot ZOZ będący poprzednikiem prawnym, a kwestia wydatkowania miała dotyczyć następcy prawnego, czyli powiatu.

Konieczność wskazania obszaru nieostrości, który de facto wypełnił NSA w glosowanym wyroku, jest konsekwencją sformułowania, jakie przyjął normodawca w przepisie art. 17 ust. 1b u.p.d.o.p. O ile bowiem w przypadku art. 17 ust. 1 pkt 4 ustawy końcowa część tej regulacji pozwala sformułować wymóg bezpośredniości, który wskazał NSA w Warszawie, powołując się przy tym na przywołany wyrok NSA w Warszawie z dnia 20 listopada 2000 r., FPS 9/00, to już trudniej jest sformułować taki wymóg, gdy idzie o wydatkowanie tych środków w oparciu o wskazany art. 17 ust. 1b u.p.d.o.p. Wydaje się, że taki wymóg wynika z funkcjonalnego powiązania pomiędzy przeznaczeniem a wydatkowaniem dochodów na dany cel statutowy, nawet wówczas, gdy tym celem jest konkretnie określona działalność w sensie jej rodzaju czy też w sensie zakresu danej działalności.

Naczelny Sąd Administracyjny w Warszawie sformułował tezę o tożsamości tych celów statutowych, a zatem w tym przypadku tożsamości celu w postaci działalności w zakresie ochrony zdrowia. Przyjęta teza o tożsamości celów, jeśli chodzi o przeznaczenie dochodów i ich wydatkowanie, jest niewątpliwie uzasadniona i mieści się w przepisie art. 17 ust. 1b u.p.d.o.p. Przy czym należy zauważyć, że owa tożsamość odnosi się w rezultacie do działalności albo konkretnie oznaczanej rodzajowo bądź też działalności w określonym zakresie, czyli w tym przypadku w zakresie ochrony zdrowia. Można przyjąć, iż znacznie łatwiej jest wyrazić tezę o tożsamości celów w sytuacji, gdy dotyczy ona konkretnej działalności, niż samego celu sensu stricto. W przypadku bowiem sprawy będącej przedmiotem orzeczenia NSA w Warszawie chodziło o sytuację, gdy poprzednik prawny był podmiotem leczniczym - ZOZ-em - gdzie niewątpliwie cele statutowe dotyczą działalności w zakresie ochrony zdrowia, natomiast jego następca prawny, a zatem powiat, ma jedynie 
ustawowo określone zadania na rzecz promocji i ochrony zdrowia ${ }^{7}$. Przyjęcie jedynie pojęcia celu sensu stricto, a zatem bez identyfikowania z konkretną działalnością, dawałoby możliwość kwalifikowania również w tym obszarze wydatków ponoszonych przez powiat jako podlegających zwolnieniu. Jednakże z uwagi na identyfikowanie celu przez ustawodawcę podatkowego z działalnością w praktyce dla zastosowania zwolnienia podatkowego wymagane jest wydatkowanie przez określony podmiot dochodów na ten konkretny rodzaj działalności bądź ten konkretny zakres działalności, którego dotyczyły przeznaczone dochody. Zasadnie zatem podkreślił NSA w glosowanym wyroku, że ,Nie wystarczy zatem zbieżność ogólnie zakreślonego zadania przypisanego powiatowi mocą art. 4 ust. 1 pkt 2 ustawy o samorządzie powiatowym z zadaniami ZOZ-u (...)”.

W praktyce należy zatem odróżniać obszar nieostrości, jaki jest konsekwencją sformułowania „dochody wydatkowane na konkretny cel” w znaczeniu konkretnej działalności, od tych przypadków, gdy wydatkowanie można umieścić w ogólnie określonym celu, który nie jest konsekwencją identyfikowania celu z działalnością. Dla zastosowania zwolnienia z art. 17 ust. 1 pkt 4 u.p.d.o.p. należy wziąć pod uwagę wyłącznie ten obszar nieostrości, który jest konsekwencją identyfikowania celu z określoną działalnością. Potwierdził to także NSA w glosowanym wyroku stwierdzając, że ,„(...) zadaniem powiatu w zakresie ochrony zdrowia jest działalność polegająca na stworzeniu warunków do realizacji ochrony zdrowia, a nie udzielanie świadczeń zdrowotnych.”

\section{4.}

Pogląd przyjęty przez NSA w Warszawie w glosowanym wyroku potwierdza, że w praktyce podatkowej sądy właściwie precyzują obszar nieostrości mimo problemów, jakie można wskazać, jeśli chodzi o pewną różnicę pojęciową między celem i działalnością. Niewątpliwie poprzestanie przez ustawodawcę podatkowym na samym wyrażeniu celu statuto-

Zgodnie z art. 4 ust. 1 pkt 2 ustawy z dnia 5 czerwca 1998 r. o samorządzie powiatowym (tekst jedn. Dz.U. z 2016 r., poz. 814 ze zm.). 
wego, bez jego - tak jak w obecnym kształcie - identyfikowania pod względem zakresu z działalnością znacznie rozszerzyłoby obszar nieostrości, dając możliwość stosowania zwolnienia dla szerszego zakresu sytuacji niewyznaczonych jedynie samą działalnością w danym celu statutowym. Można zatem stwierdzić - tak jak uczynił to NSA w glosowanym wyroku - że relacje pomiędzy tymi obszarami nieostrości można przedstawić jako tożsamość celów. Chodzi zatem w rezultacie o tożsamość działalności, gdy chodzi zarówno o konkretny jej rodzaj, jak i o działalność w danym zakresie.

Konieczność wskazywania w praktyce tej relacji jest dodatkowo wzmocniona kształtem regulacji, jakich użył normodawca w analizowanych przepisach. Podczas gdy w przepisie art. 17 ust. 1 pkt 4 u.p.d.o.p. ustawodawca podatkowy wskazuje na te cele, to już w regulacji art. 17 ust. 1 b u.p.d.o.p. odnosi się do całej regulacji art. 17 ust. 1 ustawy, gdzie chodzi nie tylko o cele statutowe, ale także inne cele $\mathrm{z}$ tego unormowania. A zatem uzupełnienie, będące $\mathrm{w}$ rezultacie ograniczeniem obszaru nieostrości w stosunku do wszystkich sytuacji wskazanych w przepisie art. 17 ust. 1 u.p.d.o.p. zawarł normodawca w jednej regulacji. Takie rozwiązanie jest uzasadnione techniką legislacyjną, a także względami racjonalnego ustawodawcy, niemniej stawia dla praktyki podatkowej poważne wyzwanie dla ukazywania tej relacji pomiędzy wskazanymi obszarami nieostrości. Ponadto konieczność ukazywania tej relacji jawi się także jako konsekwencja sformułowania użytego w przepisie art. 17 ust. 1b u.p.d.o.p. Ustawodawca powtarza bowiem wymóg przeznaczenia, który został już wyrażony w przepisie art. 17 ust. 1 pkt 4 u.p.d.o.p. Rozwiązanie to jest zapewne uzasadnione kształtem różnych unormowań przepisu art. 17 ust. 1 ustawy, gdzie normodawca, także poza analizowanym przepisem art. 17 ust. 1 pkt 4, umieszcza inne przypadki odnoszące się do przeznaczenia dochodów na cele statutowe bądź też inne cele wyrażone w tym przepisie. Niemniej jednak takie powtórzenie wymogu przeznaczenia w tym przypadku, jak w analizowanym art. 17 ust. 1 pkt 4 ustawy, wydaje się zbędne, a może co najwyżej powodować wątpliwości, gdy idzie o wspominaną relację. Niewątpliwie nie można tego sformułowania postrzegać w taki sposób, iż ustawodawca wprowadza inne relacje pomiędzy 
obszarem nieostrości wskazanym $\mathrm{w}$ przepisie art. 17 ust. 1 pkt 4 u.p.d.o.p., a tym dotyczącym dochodów wydatkowanych na cele statutowe $\mathrm{z}$ art. 17 ust. $1 \mathrm{~b}$ ustawy.

\section{5.}

Zadaniem orzecznictwa podatkowego jest niewątpliwie precyzowanie obszaru nieostrości, jaki powstaje jako skutek zastosowania w danym elemencie konstrukcji prawnej podatku (także elemencie stosunku prawnego zobowiązania podatkowego) takiego środka techniki prawodawczej, który zapewnia elastyczność przepisów prawa podatkowego. Rola sądów administracyjnych przejawia się zatem w ukazywaniu relacji pomiędzy tekstem prawnym „tu i teraz” a dynamicznie rozwijającą się rzeczywistością społeczno-gospodarczą. Szczególne znaczenie powinno odgrywać orzecznictwo podatkowe w tych sytuacjach, w których ustawodawca podatkowy niewłaściwie umieszcza dany środek techniki prawodawczej zapewniający elastyczność przepisów prawa podatkowego. Analiza bowiem orzeczeń sądów administracyjnych pozwoli na dokonanie weryfikacji rozwiązań normatywnych.

\section{Bibliografia:}

Bogucka I., Funkcje prawa. Analiza pojęcia, Zakamycze, Kraków 2000.

Borszowski P., Określenia nieostre i klauzule generalne w prawie podatkowym, Wolters Kluwer, Warszawa 2017.

Małecki P., Mazurkiewicz M., CIT. Podatki i rachunkowość. Komentarz, wyd. VII, Lex, Komentarz do art. 17. 